\title{
The Fate of Former Military Complexes and Areas
}

\author{
SCHLEICHER Alexander ${ }^{1, a^{*}}$ \\ ${ }^{1}$ Institute of Public Buildings, Faculty of Architecture, Slovak University of Technology in \\ Bratislava, Námestie Slobody 19, 81245 Bratislava 1, Slovakia \\ aalexander.schleicher@spde.sk
}

\begin{abstract}
Keywords: Military Area, Military Base, Missile Base, Military Object, Casern, Cultural Centre, Museum, Transformation, Reconstruction
\end{abstract}

\begin{abstract}
Objects or parts of urban structures which no longer fulfill their original function are losing life and often become the neuralgic points of our living environment. We got used to - for example - dysfunctional industrial architecture finding new utilization and providing a reliable basis for creating museums or cultural centers. What is the situation with former military complexes and areas? Are they capable of providing a good starting point and spatial setting for a museum or cultural center as well? The examples of realizations Chinati Foundation in Marfa, Raketenstation Hombroich by Neuss and Kasárne/Kulturpark in Košice prove that they are. Three similar and yet different examples of former military areas and complexes conversions show the way it is possible to revive forgotten, lethargic and often almost dead objects and areas.
\end{abstract}

\section{Introduction}

The artificial environment created by humans for some particular function has always its limits depending on various aspects - often it is determined by economic conditions or constraints influencing a whole spectrum of human and social activities and behaviour. Not of less importance are the social, political or natural conditions. In case of disadvantageous setting of one or more of the factors often the life of a building, area, urban complex or even a town ends. They stopped serving the function they were formerly dedicated to. In some cases we are witnessing a consecutive assimilation and adapting to a new situation, though often this adaptation is undignified. As an example let's mention a characteristic transformation of former "houses of culture" from the socialistic era in the post totalitarian time in Slovak republic. The development of small business and market functions sometimes enabled culture to vegetate but sometimes completely pushed it away - in this process the building with partially preserved former function or brand new one survived. In extreme cases of inability to adapt to new conditions, not only speaking of the former houses of culture, we come across necrotic dysfunctional and empty objects or more extensive parts of artificial human environment. The distinctive neuralgic points of the environment are mainly industrial, traffic buildings or warehouses and areas or complexes. The question is which one of the mentioned cases is worse - degrading former honourable function, for example culture, and letting it survive in unworthy conditions of an inadequate adaptation without any chance to a better new life or the clinical death of architecture or urban complex with a potential of Phoenix. It's important to add that new adequate restart of an object which lost its former function is not always a rule in a world turning around according to the rules of economic feasibility. Despite indisputable qualities of industrial architecture which has an undoubtable potential to be converted to cultural and sometimes even other functions such as offices, housing etc. fulfilling such intent is usually supported by respect to values of the past, often almost sentimental, strong conviction and good financial background. A former factory, power plant or warehouse - above all the ones with a certain historical value, are according to the nature of their architecture directly predestined to a conversion to cultural function, they have an acceptable space setting and dimension limits. What is the situation with more or less specific military areas, which lost their former purpose? 
As two characteristic cases we can present Chinati Foundation in Marfa, Texas (USA) and Stiftung Insel Hombroich in Neuss (Germany). An example which is a bit different is the Kasarne/Kulturpark Košice (Slovak republic).

\section{Chinati Foundation, Marfa}

Chinati Foundation resides in a small town Marfa on the south-west of Texas. The institution was established by a well-known American sculptor Donald Judd to present his own artistic work as well as the work of his colleagues - John Chamberlain and Dan Flavin. During the years the collections were extended by the works of further artists, currently the institution serves for creative stays of artists and sponsors artistic and educational programmes. Though the institution possesses several objects directly in Marfa, the most important part of it is a former military area Fort D. A. Russel on the town periphery. The history of the military area formerly known as Camp Marfa reaches to the year 1911, when the cavalry built the first camp south-west of Marfa. The military area served army with a break in the 30-ties of the $20^{\text {th }}$ century. After that it served to different types of military units or even as a war prisoner camp during the World War II. The end of World War II also meant the end of the military base. In the year 1949 the army sold its properties and gave donated estates back to Marfa. Part of the objects serving to the army especially the officers' houses were easily usable for civil inhabitants, some objects were rebuilt to new functions serving the town, for example warehouses or housing for senior citizens. Bigger part of the area was deteriorating until the 70-ties of the $20^{\text {th }}$ century when what now is the basis of Chinati Foundation was founded. For the successful transformation of a damaged area to a known museum and cultural centre an optimal constellation of multiple circumstances was necessary. The artist Donald Judd led the critique aimed against "the modern exhibition machinery wherein art works are time and again continually traveling to new places, often exhibited in not very ideal situations and always endangered of being damaged by improper handling" [1] for a long time as well as against museum architecture and the creators of museum buildings: „Forms' for their own sake, despite function, are ridiculous. One reason art museums are so popular with architects and so bizarre, is that they must think there is no function, the clients too, since to them art is meaningless. Museums have become an exaggerated, distorted and idle expression for their architects, most of whom are incapable of 'expression.“ That's why he also posed the question: „Why are artists and sculptors not asked how to construct this type of building?" [2] Judd's efforts to create an ideal museum had started in the 60 -ties of the $20^{\text {th }}$ century in New York by adapting at first small spaces for an exhibition of his own works and in the year 1968 by buying a whole five storey historic building. He intended to adjust it so that it would serve to exhibiting art. Since 1973 the artist buys several vast estates in Marfa, his effort culminates in the year 1979 by the acquisition of an extensive former military area Fort D. A. Russel - whole blocks of former military buildings and land with area of almost $1,4 \mathrm{~km}^{2}$. The acquisition was possible thanks to its financial expedience. In the beginning he invests his own financial resources, later he continues with help from Dia Art Foundation. The area has an ideal potential to fulfil Judd's intents. His ambition was to provide to the works of contemporary art, not only his own, a fixed place where they could fully and uninterrupted in calm and ideal spatial conditions entwine their acting. Since the 70-ties Judd had been intensely dedicated besides visual art also to design of furniture and architecture. In the year 1979 he begins with Fort D. A. Russel reconstruction and creating artistic installations within the area, in the year 1986 an independent non-profit public funded institution Chinati Foundation was open. A big advantage for D. Judd was the size of the area enabling large exterior installations, for example his concrete sculptures, as well as the number and size of particular military objects providing potential for comprehensive installations of individual artists, whose work is included in the collection in separate buildings or groups of buildings. The architectonic character of Chinati Foundation was created by D. Judd by interventions in spirit of his minimalist conviction with effort to optimize the functioning which for the author is inseparably connected with furniture design and architecture. He respected the former 
objects pretty much though. Judd works especially with the inner open space, light and the spirit in the interior.

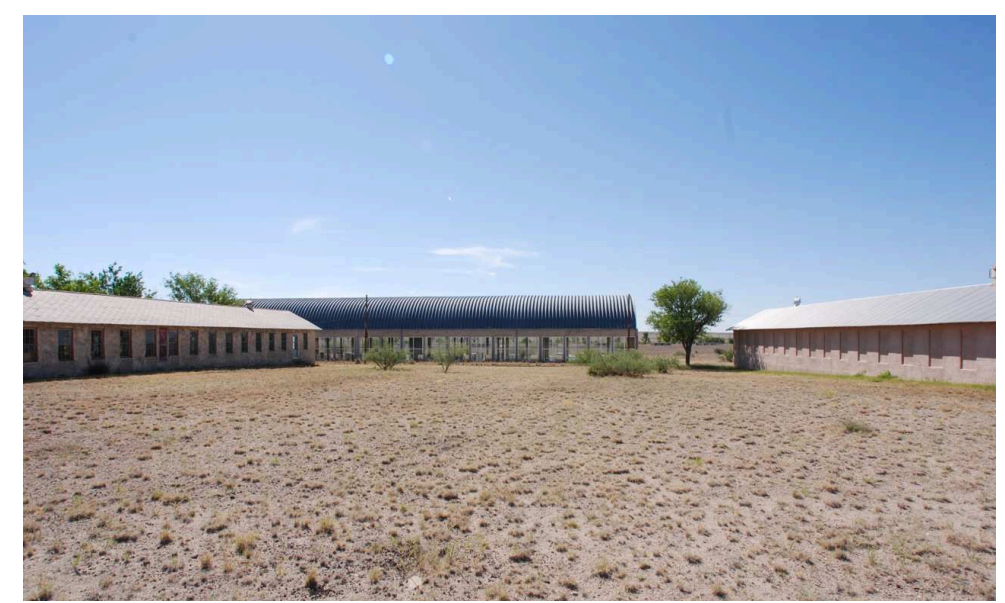

Fig.1, Chinati Foundation Marfa, Former artillery shed and U-shaped army barracks. Project by D. Judd, Photo by Marcus Trimble [3]

Judd's intervention in Marfa brought life to a, after the departure of army gradually more and more drowsy, town. It stirred up the art life and D. Judd was successful at getting this town on the culture map of the world as an important visual arts destination. The presence of Chinati Foundation and also the cooperating Judd Foundation started art life in the town and other known cultural institutions were established there. For example Ballroom Marfa was created by adapting a dance room from the year 1926 to an exhibition space, under its conduction a world-wide known architecturally-artistic installation Prada Marfa was created, there are regularly festivals of visual arts, film and music organized in town.

\section{Stiftunf Insel Hombroich, Neuss}

Stiftunf Insel Hombroich is located on periphery of town Neuss, in northern Rheinland Westphalia. The unique institution dedicated to art and culture consists of three main parts - the former Museum Insel Hombroich area, newer part Raketenstation Hombroich, created from a former NATO missile base and the part Kirkeby-Feld, located in centre between the two other. Stiftung Insel Hombroich as a connection of these three parts was established in 1997, its development started in the first half of the 80 -ties of the $20^{\text {th }}$ century. That is when a real estate agent and art patron Karl-Heinrich Müller started to materialize his dreams and create an asylum for friends of art and nature in spirit of Cézanne's principle "art in parallel to nature" [4] by building the area Museum Insel Hombroich in natural environment around a classicist villa located near the river Erft. The museum was open in 1987. In 1994 K.-H. Müller bought a nearby former NATO missile base, what enabled a radical development of the facility. Raketenstation Hombroich formerly served as a part of NATO air defences. After the end of cold war the NATO basis was cancelled. For K.-H. Müller this vast 13 hectares area provided an ideal spatial setting for expansion and philosophical extension of Museum Insel Hombroich. Halls, hangars, ground mounds and observation tower were reconstructed and rebuilt; the area was complemented with further objects and art installations, creating the area visual expression. Besides Erwin Heerich who imprinted character to the former Museum Insel Hombroich, other internationally accepted artists and architects - Raimund Abraham, Tadao Ando, Oliver Kruse, Katsuhito Nishikawa and Alvaro Siza were invited. In the area there are several objects by E. Heerich - archive and library, residential house, Kloster and Fontana Pavilion, which have architecturalized forms of author's art works such as the ones in Museum Insel Hombroich. They are concretists' sculptures with simple principles deriving their expression from consistent reduction of materials and proportions. The objects are connected by used material - 
brickwork from recycled bricks in the exterior, the interiors are simply plastered. Alvaro Siza created the Siza Pavilion serving as Institute of Architecture, exhibition and congress spaces. A. Siza in the spirit of the basic principles of his work remains with poetic simplicity; as the basic means of expression just like E. Heerich he uses brickwork on the exterior and for his work typical plain white walls in this case combined with wooden floors and ceilings in the interior. Raimund Abraham created the sculptural Abraham Gebäude characteristic by its volumes. Besides musicians' and composers' residences it serves as a chamber concert hall, studio and musical library. Within the complex we can also find a museum by Tadao Ando Langen Fundation with the status of an independently functioning institution. The museum is focused on modern oriental art, a diverse nature of the collection is reflected by the exterior expression of the object; T. Ando used traditional materials for his work, he combines volumes of two partially sunk concrete blocks dedicated to modern art exhibition and a glass pavilion with inserted concrete block dedicated to Japanese art exhibition. The object expression is emphasized by natural environment in which the object is situated and a water surface on which the glass volume of the museum partially levitates. In the area there are several sculptures and spatial installations by Katsuhito Nishikawa, Oliver Kruse, Erwin Heerich, Michael Growe, Heinz Baumüller and Eduard Chillid.

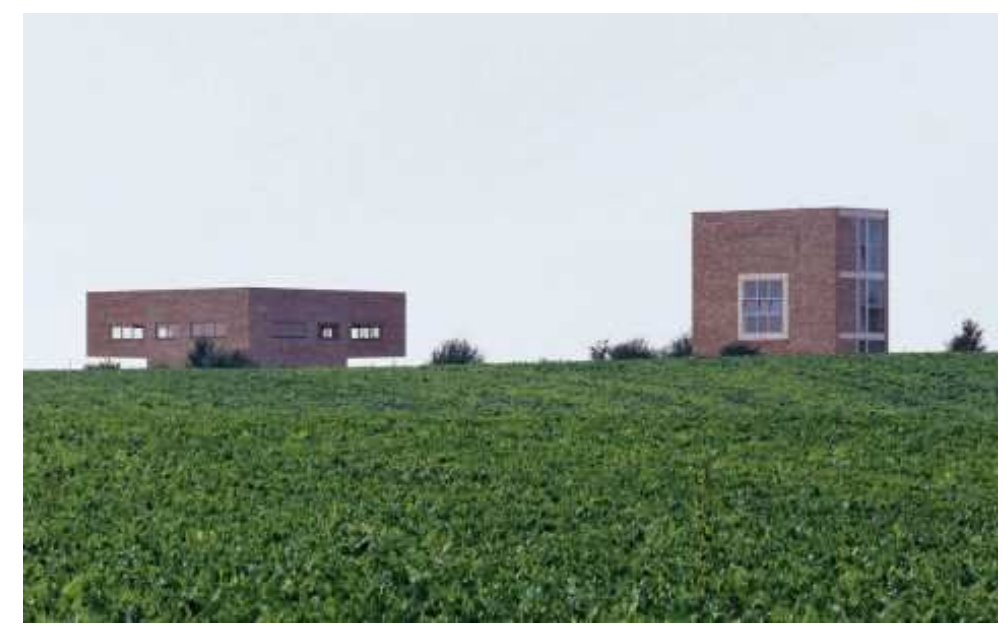

Fig. 2, Raketenstation Hombroich, Archive and library (1999-2000) and residential building (19992001), Architect: E. Heerich, Photo by Stiftung Insel Hombroich [5]

Raketenstation Hombroich not only serves as a museum but above all it is a creative platform, extension of the idea of artists working in a complex which started already in the Museum Hombroich. Visual artists, writers, composers and scientists of various nations coming from various cultural environments live and work here.

\section{Kasárne/Kultrupark, Košice}

Kasárne/Kulturpark Košice was created by adaption of former military object - former Casern of CPT Jaroš on the Skladná Street in Košice. The objects were built into a valuable historical park, so called Saffron garden. The complex of buildings on a 3 hectares plot was constructed in the end of the $19^{\text {th }}$ century. The transformation of the casern to a cultural centre was realised especially as a part of the Košice European Capital of Culture 2013 event; Kasárne/Kulturpark was the biggest financial investment within mentioned event. The current form of Kasárne/Kulturpark stems from the winning competition entry of the studio zerozero (architect Irakli Eristavi) in the architectural competition organized at the turn of 2009-2010. The concept of Kasárne/Kulturpark as a wide-range cultural centre operated with several factors. The basis was an advantageous location in a broader centre with direct connection to the very centre and intentions to create public spaces - urban area, so called forum on the border of cultural centre and town. The forum creates an area defined by a grid, in the competition entry consisting of variously defined pixels, variable platforms for different 
types of activities and events. As the architect says in the description: "The grid is a clue to particular programmes, activities location and doesn't prescribe their architectural form." [6] Unfortunately the reconstruction due to owners' relationships couldn't include complexly the whole area, Kasárne/Kulturpark is created by three main objects (out of six main objects of the former area) named Alfa, Bravo, Charlie and several smaller pavilions also named in spirit of the international military phonetic alphabet. The navigation point of the complex from where the major part of the area is visible and from where the names of the objects are projected onto their facades is called Zulu. The architectural face of Kasárne/Kulturpark is a combination of white simplicity of reconstructed historical objects and simplicity and purity of the new forms of added pavilions and public spaces. All this is colored by the greenery of the historical park.

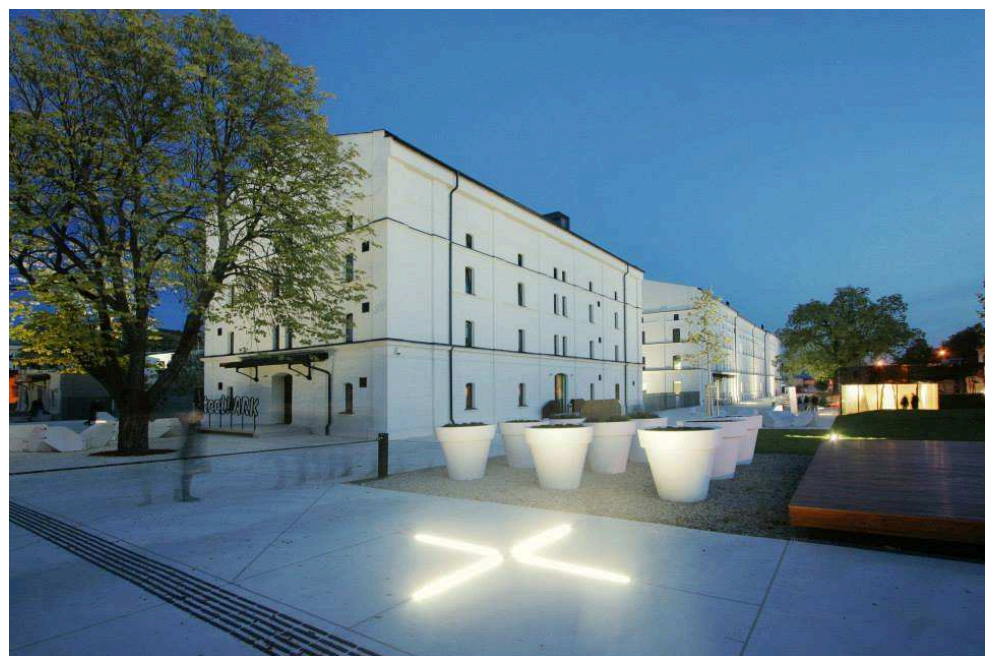

Fig. 3, Kasárne/Kulturpark Košice, Charlie and Bravo buildings (2013), Architect: I. Eristavi, zerozero, Photo by K13 [7]

In Kasárne/Kulturpark ateliers, workshops, studios, classrooms found their place; in the main building Alfa we find two multifunctional halls used for concerts, theatre performances, lectures and conferences, at the same time there are two smaller multifunctional dance halls, sound studio and video studio. A separate part of the complex is created by exhibition spaces. Within the complex there also is a kids and youth library and a creative factory Steelpark. There is also a Pavilion for residents - Lima which serves as a background and art workshop for residents and performers working and performing in the complex. By transforming the casern a complex background for creating, presentation and support of art and contemporary creative, authentic and experimental culture was created. The aim of the cultural centre is to provide space for creating and presenting multi-genre artistic production of high quality.

\section{Similarities and Dissimilarities}

Despite the common starting point of all three examples - they all are conversions of former military areas, these examples are very dissimilar. Chinati Foundation and Raketenstation Hombroich are by its location on a town periphery in natural environment and by the importance of the town Marfa in a diametrically different situation as Kasárne/Kulturpark which is a part of a dense urban structure near to the very centre of Košice and it uses this location to the full. This fact is reflected in better or worse possibilities to acquire the area as a whole and the financial expedience of such acquisition. This is where the benefit of advantageous and simply acquirable eccentrically located and often enormously vast areas which for the reason of atypical location and excessive dimensions are less marketable steps up. In case of Chinati Foundation and Raketenstation Hombroich the eccentric locations and dimensions of the areas didn't represent an obstacle to the intents of their founders; we can say that on the contrary, calm and nature distant form the city make the areas thrive. In the particular examples we can see a different level of 
interventions into existing complexes. It is determined by the importance or value of architecture which serves as basis for the transformation. In case of Raketenstation Hombroich we cannot talk about a strong architecture as a basis for the new function. Positive is rather the spatial setting and nature; this is what the founder K.-H. Müller is aware of and despite reconstructing some of the former objects he mainly brings many new objects, often almost sculptures, which set the new nature of the institution. In Chinati Foundation the existing devastated architecture didn't bear exceptional values, the founder and author D. Judd makes full use of the values of the existing basis though and intervenes to the area in a very distinguished way. The author's approach is very present but at the same time it is respecting the existing, the autonomous approach can be seen especially in the exterior installations of the artistic works. In case of Kasárne/Kulturpark there was an existing urban and architectural basis of high quality with a strong potential. It was properly used and complemented by an autonomous author's approach in form of small pavilions and the design of public spaces and greenery. The way of financing of the particular examples differs as well. It set the limits of possible and impossible and defined the elementary start line and approach. Whilst Kasárne/Kulturpark is supported by public resources - European Union funds mainly complemented by state and municipality financing, Chinati Foundation and Raketenstation Hombroich are supported mainly by private investments, foundations and donors.

Despite many differences of mentioned examples, every building is a unique original coming out from a different start point, it is necessary to come back to the start and point out what is the connection between these three and that is the new life. New life is always sublime but in this case it applies even more, just as it is mentioned in the basic characteristic of Kasárne/Kulturpark: "Before only the stamping of military boots and severe commands were heard here. Today everything is different; solely the dancers and artists are "marching" here." [7]

\section{References}

[1] D. Judd, The Marfa Project 1973-1979, in: E. Köb (Ed.), Museum architecture: Texts and Projects by Artists, Buchhandlung Walter König, Cologne, 2000, p. 48.

[2] E. Köb, The Voice of The Artist, in: E. Köb (Ed.), Museum architecture: Texts and Projects by Artists, Buchhandlung Walter König, Cologne, 2000, p. 7.

[3] Information on https://www.flickr.com/photos/gravestmor/4702181936

[4] Information on http://www.inselhombroich.de/museum-insel-hombroich/museum/?lang=en

[5] Information on http://www.inselhombroich.de/raketenstation-hombroich/?lang=en

[6] I. Eristavi, Sút’až Kasárne Kulturpark Košice 1. cena (Competition Kasárne Kulturpark Košice $1^{\text {st }}$ prize), Projekt. 2 (2010), p. 10.

[7] Information on http:/www.k13.sk/o-nas/centra/kasarne-kulturpark/ 